Status Report 2016-2019

\title{
Magnetotelluric Investigations in India During Last Five Years
}

\author{
M ISRAIL $^{1, *}$, DHARMENDRA KUMAR ${ }^{1}$, ANITA DEVI ${ }^{1}$ and PRAVIN K GUPTA ${ }^{1}$ \\ ${ }^{1}$ Department of Earth Sciences, IIT Roorkee, Roorkee, India
}

(Received on 25 August 2019; Accepted on 29 September 2019)

\begin{abstract}
This paper reviews the Magnetotelluric (MT) studies carried out in India during last five years. These MT field studies covered area, which includes Garhwal Himalaya, Sikkim Himalaya; Indo-Gangetic Plain (IGP); Gujrat, Dharwar craton (DC), Eastern Ghat Mobile Belt (EGMB), North Singhbhum Mobile Belt (NSMB), Dalma basalts, Dharwar region, Central Indian Shear (CIS) zone, Narmada-Son Lineament (NSL), Cuddapah basin, Banaganapalli quartzites, Narji limestone, Koyna-Warna and 3D MT inversion software- AP3DMT. The field investigations aimed to delineate deep crustal structure, the basement depth geometry, resistivity structure in the Bhuj earthquake region, electrical resistivity characterization of Fault zones, mapping of geothermal source zone, lithosphere architecture. Software, AP3DMT-MATLAB code for 3D inversion of MT data was developed and tested. This code is made versatile and user friendly by an efficient use of MATLAB's inbuilt functions.
\end{abstract}

Keywords: Magnetotellurics; Bhuj Earthquake; Geothermal; Hot Spring; 3D MT Inversion; AP3DMT

\section{Introduction}

Magnetotelluric(MT) methods have used to investigate various problems, at different depth scales, in diverse geological environment. MT data comprises natural time varying orthogonal components of electric and magnetic fields. Its interpretation provides electrical resistivity image of the earth's interior. Electrical resistivity is sensitive to the amount of fluid/water present in pore spaces, to salinity of fluid, to temperature, to the amounts of partial melt, graphite and conducting minerals present in the subsurface formations. The derived electrical resistivity image of the subsurface can be used to decipher the amount and type of fluid distributed in pore spaces, to decipher the geothermal reservoir, the amounts of partial melt and conducting minerals present in the crust. This information can be used to solve various problems related to crustal structure, fault geometry in depth, earthquake related studies, geothermal, mineral and hydrocarbon exploration.

Several academic institutions and research laboratories are equipped with MT data acquisition, processing and multi-dimensional modelling and inversion facilities. The Indian groups involved in MT field investigations and theoretical development works, along with their recent contributions, are listed in Table 1. These groups have recorded and/or used, during 2015-19, a total of 721 sites spread over 40 profiles from different parts of India. From north to south, the various groups actively pursuing MT studies include WIHG, IITR, KUK, ISM(IIT), ISR, GERMI, IITB, IIGM, AU, OU, CSIR-NGRI. These groups have worked in different parts of India, e. g. IITR, KUK, CSIR-NGRI have worked in Himalayan region for deep crustal structure studies in Garhwal Himalaya and Sikkim Himalaya (Devi et al., 2019, Israil et al. 2016; Kumar et al., 2018b). CSIR-NGRI group has worked in Indo-Gangetic Plain (IGP) to delineate the basement depth geometry in Hamirpur-Rupadiah profile (Manglik et al. 2015). KUK, ISR, GERMI, IIGM, AU, CSIR-NGRI, OU, ISM (IIT), and IITB, groups worked in peninsular region. Major MT studies were conducted in Gujrat: (i) ISR, GERMI, AU, CSIR-NGRI and IITB groups worked in and around the Bhuj earthquake zone of 2001 (Mohan et al. 2015; Begum and Harinarayana 2016; Azeez et al. 2018), (ii) ISR and KUK groups worked for the electrical

*Authorfor Correspondence: E-mail:mohdfes@iitrac.in; mohammad.israil@gmail.com 
characterization of Kachchh Mainland Fault (KMF), Katrol Hill Fault (KHF) and Ulat-Kotda fault (UKF) (Mohan et al., 2018a). CSIR-NGRI groups carried out Fault zone mapping around Godhra, Cambay and Saurashtra regions (Kumar et al. 2018c; Mohan et al., 2018b; Danda et al., 2017; Mohan et al., 2019). ISR group mapped geothermal source zone (Chabsar hotwater spring) (Mohan et al. 2017).

Dharwar craton (DC) and Eastern Ghat Mobile Belt (EGMB), lithosphere architecture of the cratonic domain were investigated by IITB, ISM (IIT), UCIL, CIST, CSIR-NGRI groups (Chandrasekhar et al., 2018; Singh et al., 2018; Malleswari et al., 2019; Pratap et al. 2018; Kusham et al., 2018). Few MT traverses, cutting across the Western Ghat and east of the Western Ghat belt, were investigated by CSIRNGRI group (Patro et al. 2018). North Singhbhum Mobile Belt (NSMB) and Dalma basalts of Proterozoic ages were mapped through resistivity model derived from MT data by ISM (IIT) group, (Maurya et al. 2015, 18). CSIR-NGRI and CIST groups worked in Dharwar region (Malleswari et al. 2019; Pratap et al. 2018; Kusham et al. 2018). CSIRNGRI group investigated the Central Indian Shear (CIS) zone and Narmada-Son Lineament (NSL) of the Central Indian Tectonic Zone (CITZ), (Azeez et al. 2017; Azeez, 2016; Patro and Sharma, 2016). The electrical structure of the crust was estimated by CSIR-NGRI group (Patro and Sharma, 2016), using 3D MT, beneath the western segment of NSL zone in Central India. IIGM, CSRI- NGRI, groups worked in Cuddapah basin where the low resistivity features were correlated with the presence of base metals $(\mathrm{Cu}, \mathrm{Pb}, \mathrm{Zn})$ in the Banaganapalli quartzites and Narji limestone (Konda et al. 2015). CSIR-NGRI, OU groups have worked in Koyna- Warna region (Patro et al., 2017). In addition to these MT field investigations, in software development, IITR group developed the MATLAB code, AP3DMT, for 3D inversion of MT data. This code is made versatile and user friendly by an efficient use of MATLAB's inbuilt functions (subroutines). In the following, we discuss the major researches carried out in India during recent past (2015-19) using 1D/2D and 3D MT field investigations with emphasis on 3D results. Finally, major features of the AP3DMT code for 3D inversion of MT data are discussed.

\section{D MT Studies in Indian Region}

Locations of 721 sites distributed along 40 profiles, are shown on the simplified tectonic map of India in Fig. 1(A). The numeral in the Fig. 1(A) indicates both the relevant reference and the profile/region. The tectonic regions covered by these MT investigations are shown in Fig. 1(B). Most of the MT profile data were inverted using standard inversion methodology available in literature and the codes are either freely/ commercially available for academic use. 3D inversions were also implemented over MT data from Gujrat, Central India and Dalma basalt regions. Topographic corrections on 3D MT from Sikkim Himalaya were applied (Kumar et al. 2018a). It is not possible to discuss all the models in this review due to limitation of space. Therefore, we briefly summarise the results with brief discussion of a few representative models from three physiographic divisions.

\section{Himalayan Region}

Kumar et al. (2018a) discussed a method for topographic corrections on 3D Magnetotelluric data recorded from Sikkim Himalaya. They used the distortion tensor stripping off technique (Larsen, 1997) and implemented topographic correction of MT data with 3D assumptions. In the 3D model, all the four components of impedance tensor are distorted due to topography, implying linear correlation between the distorted and undistorted impedance tensors. The method is demonstrated over the synthetic data generated from the model proposed by Nam et al. (2008) and on the field MT data recorded from Sikkim Himalayan region. Israil et al. (2016), discuss the existence of transverse tectonics features based on the directionality and dimensionality analyses of the MT data recorded from Garhwal Himalaya Corridor (GHC). The existence of oblique and transverse tectonics was explained in terms of geoelectric strike direction derived from the MT response. Based on their analyses the strike directions of major thrusts (MFT, MBT and MCT) were given in GHC. First 3D inversion of GHC MT data was performed recently by Devi et al. (2019) and presented their 3D inverted model of the GHC. Impedance tensor, vertical magnetic field transfer function (VTF) and phase tensor data were used in 3D inversion. Inverted model in the form of depth slices is shown in Fig. 2. The 


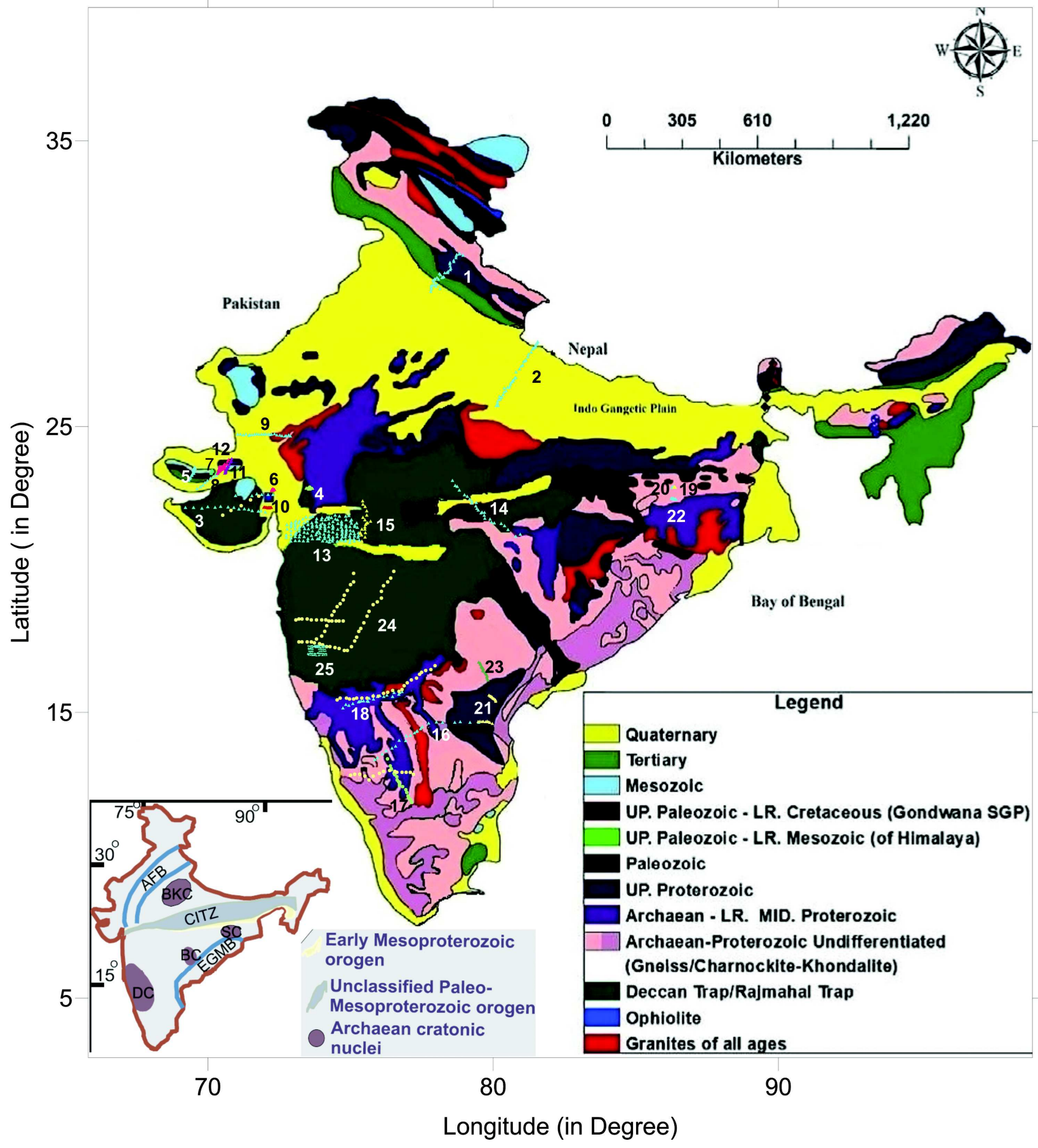

Fig. 1: (A) Simplified geological map of India showing locations of MT studies carried out during 2015-19. Locations are identified by numerals and the corresponding references shown below the map (modified after Mohan et al. 2018a). (B) The key map represents the major tectonic feature covered by MT study in India. (Modified after Kusham et al. 2018)
1 Israil et al. (2016)
9 Danda et al. (2017)
17 Pratap et al. (2018)
2 Manglik et al. (2015)
10 Mohan et al. (2019)
18 Kusham et al. (2018)
3 Kumar et al. (2018c)
11 Kumar et al. (2017)
19 Maurya et al.(2015)
12 Azeez et al. (2018)
20 Maurya et al.(2018)
5 Mohan et al. (2018a)
13 Patro and Sharma (2016)
6 Mohan et al. (2017, 4 profiles)
14 Azeez et al. (2017)
21 Chandrasekhar et al. (2018, 2 profiles)
7 Mohan et al. (2015. 2 profiles)
15 Azeez (2016)
22 Singh et al. (2018)
8 Begum and Harinarayana (2016)
16 Malleswari et al. (2019)
23 Konda et al. (2015)
24 Patro et al. (2018, 7 profiles)

25 Patro et al. (2017) 

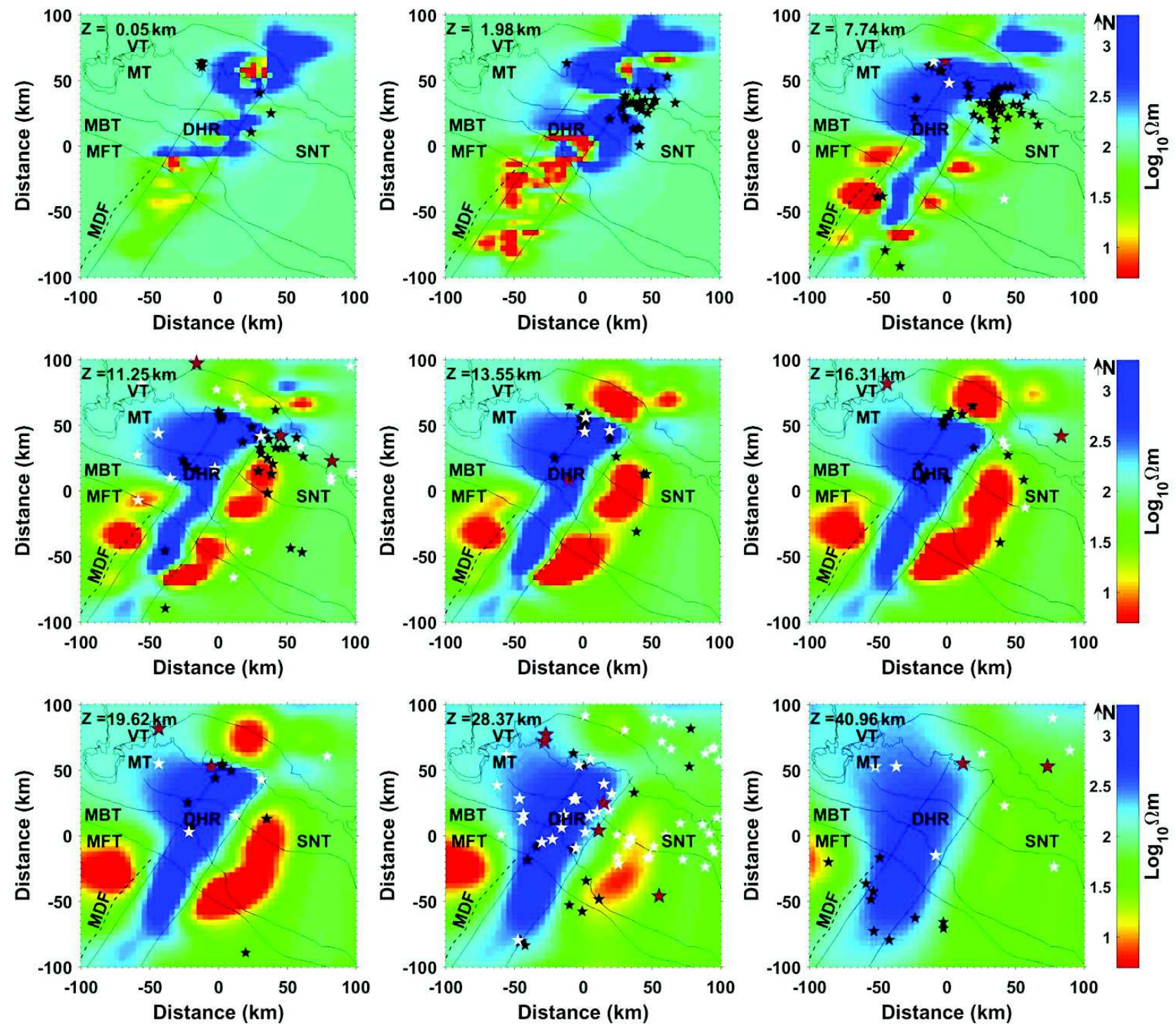

Fig. 2: Depth slices of the 3D inverted model obtained from models presented in the form of columns from left to right as VTF, PT, Z, VTF + PT and VTF + Z (Devi et al. 2019)

inverted model delineated Delhi-Haridwar Ridge (DHR) as a highly resistive $(>1000 \Omega$-m) feature beneath the low resistive $(<50 \Omega-\mathrm{m})$ sediments of the Indo-Gangetic Plain (IGP). The DHR continues up to the Inner Lesser Himalayan region, and it is bounded by two conductive $(<10 \Omega$-m) fluid-saturated fractured zones situated off-profile, and these run nearly parallel to the DHR. These features are transverse to the main Himalayan arc. The model also supports the flat ramp flat geometry of the Main Himalayan Thrust (MHT), consistent with the seismological and other geophysical models of the region.

\section{Indo-Gangetic Plain}

Electrical resistivity model along a $285 \mathrm{~km}$ long MT profile (Fig. 1(A), '2') extending between Hamirpur and Rupadia, in the indo-Gangetic plain is presented by Manglik et al. (2015). MT data was recorded at 39 sites along the profile NE-SW direction. The inverted resistivity depth model is shown in Fig. 3(A). This model shows a high resistive block in the southern end, which represents the Bundelkhand massif beneath 250-300 m thick sediments. The thickness of sediments gradually increases from south to north due to Bundelkhand Massif in the southern zone of the profile. The thickness of sediment is $500-600 \mathrm{~m}$ at 
(A)

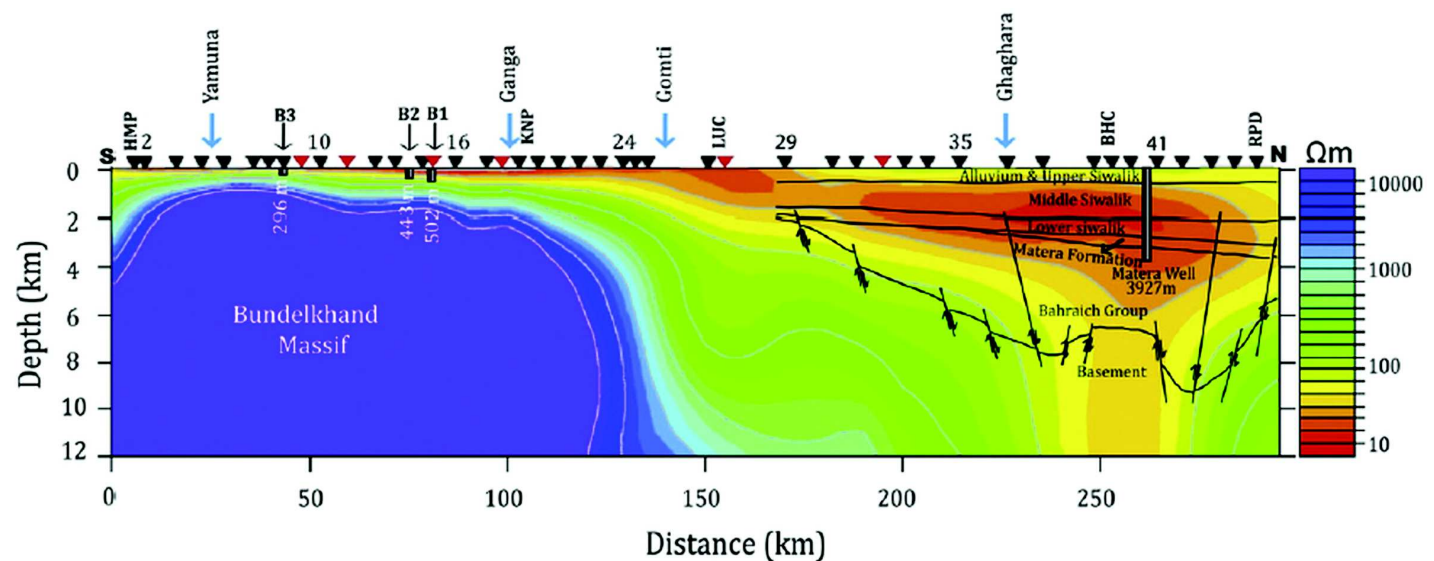

(B)

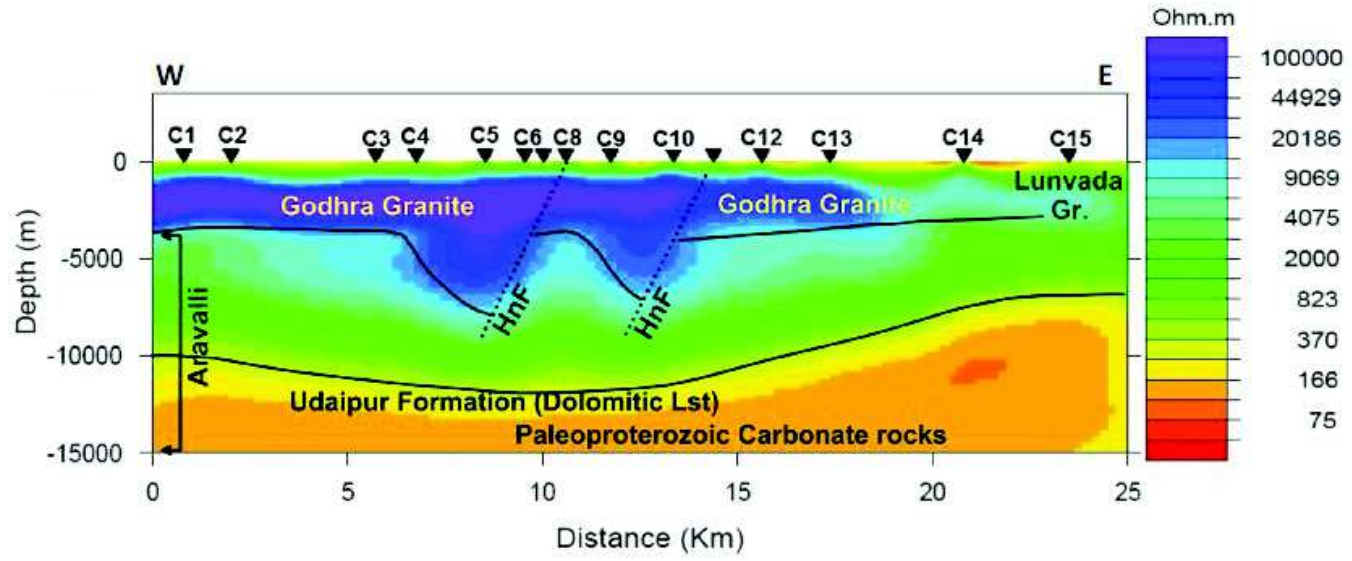

(C)
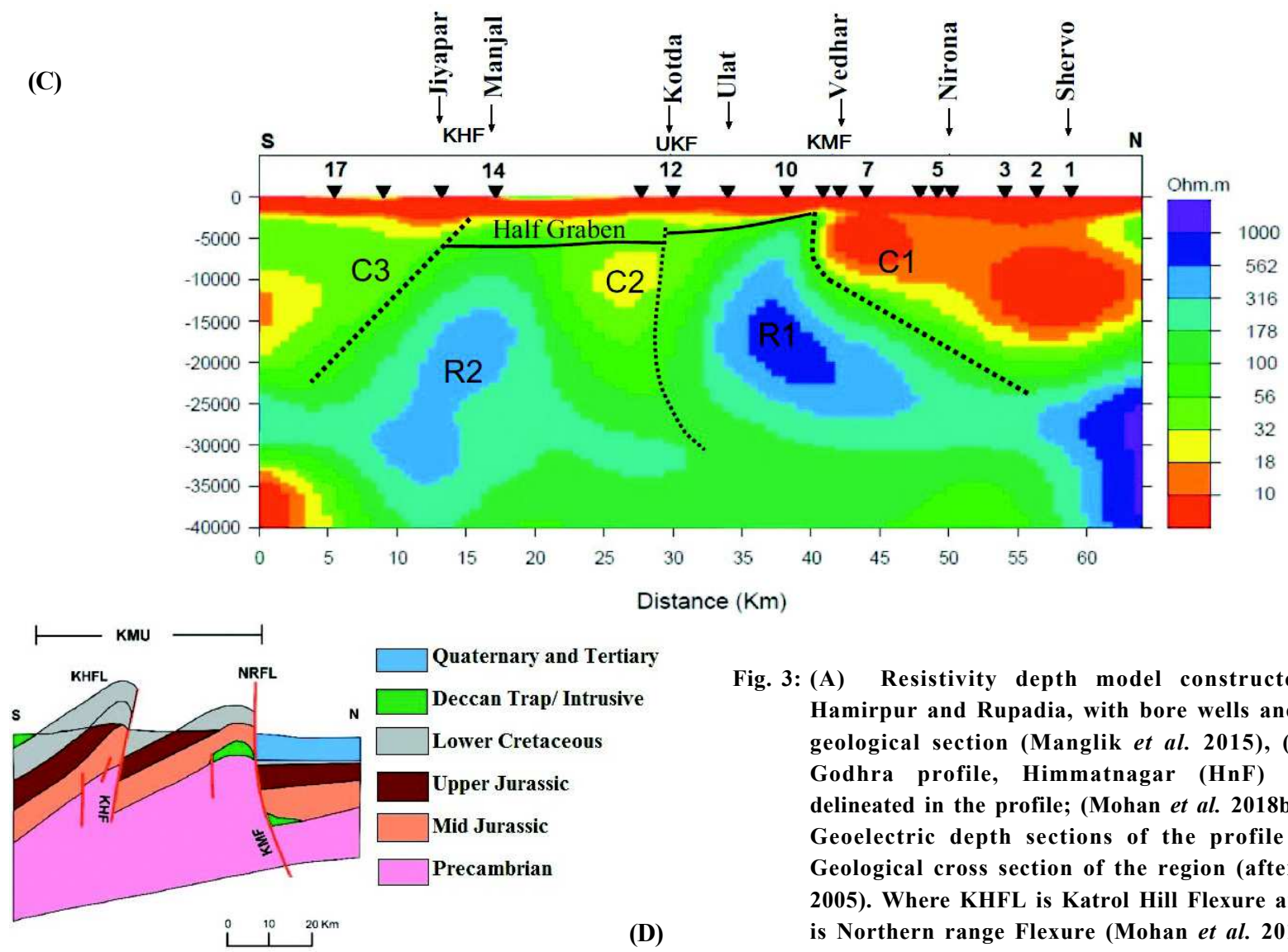

Fig. 3: (A) Resistivity depth model constructed along Hamirpur and Rupadia, with bore wells and seismogeological section (Manglik et al. 2015), (B) Tuwa Godhra profile, Himmatnagar (HnF) Fault is delineated in the profile; (Mohan et al. 2018b), (C) 2D Geoelectric depth sections of the profile and (D) Geological cross section of the region (after Biswas, 2005). Where KHFL is Katrol Hill Flexure and NRFL is Northern range Flexure (Mohan et al. 2018a) 
Kanpur, $1.2 \mathrm{~km}$ at Lucknow increasing to $9 \mathrm{~km}$ at Behraich. Lucknow fault is delineated by an abrupt increase in the sediment thickness to $2.5 \mathrm{~km}$ within a $20 \mathrm{~km}$ horizontal distance along the profile. The underlying rock is moderately resistive, representing the Vindhyan sequence.

\section{Peninsular India}

Since several MT studies were carried out in Peninsular India, these are classified regionally as; Gujrat; Dharwar Craton, Karnataka; Dalma Volcanics (DVs); North Singhbhum Mobile Belt (NSMB); Central Indian Tectonic Zone (CITZ) and NarmadaSon Lineament (NSL); Koyna Warna region, Maharashtra and Cuddapah basin. Region wise review of the research work is given below.

\section{Gujarat}

Region covered in Gujarat includes Tuwa-Godhra (Mohan et al., 2018b), Bhuj (Mohan et al., 2015), Chabsar hot spring (Mohan et al., 2017), Kachchh (Mohan et al., 2018a), Wagad (Kumar et al., 2017), Cambay (Danda et al., 2017) and Saurashtra region (Kumar et al., 2018b). The main focus of these studies was to estimate the electrical resistivity structure which, in turn, helps in delineating (i) the fault geometry, (ii) basement geometry in and around the epicentral zone of the Bhuj earthquake of 2001, (iii) tectonic configuration and (iv) mapping of geothermal source zone.

MT profile in Tuwa Godhra region is shown in Fig. 1(A), ('4'). The inverted resistivity depth model (Fig. 3(B)) shows a $500 \mathrm{~m}$ thick top layer with $<700$ $\Omega$-m resistivity. The second layer has a high resistivity $\left(10^{5} \Omega-\mathrm{m}\right)$ and a thickness of $7 \mathrm{~km}$ in the central portion of the profile. Based on stratigraphic succession, this layer is interpreted as Godhra granite. The third layer has resistivity, $60-10,000 \Omega-\mathrm{m}$, and is interpreted as Aravalli supergroup. Godhra granite and Lunavada Group contact zone can be seen as a low resistivity contrast between sites $\mathrm{C} 13$ and $\mathrm{C} 15$ (Fig. 3(B). The NW-SE striking Himmatnagar Fault ( $\mathrm{HnF}$ ) is located in the central part of the profile showing two prominent fault segments (side stepped) near Tuwa. In between the sites C3 and C12 (Fig. 3(B)), the Aravallis might have been shifted downward (about $3.5 \mathrm{~km}$ ) within the step over zone of the HnF. Electrical conductance map of Saurashtra region was presented by Kumar et al. (2018b).

Mohan and his group investigated the 2001 Bhuj earthquake region through two MT profiles (Figs. 1(A), '5' \& ' 7'). The final resistivity depth model, obtained by inverting MT response of TE $+\mathrm{TM}+\mathrm{HZ}$ modes, is shown in Fig. 3(C). The Geological cross section of the study area is shown in Fig. 3(D). This resistivity depth model reveals a low resistivity zone associated with Kachchh Mainland Fault (KMF) and South Wagad Fault (SWF). KMF fault is dipping northward and south Wagad fault is dipping southwards in the studied region. Three low resistivity zones; $\mathrm{C} 1, \mathrm{C} 2$ and $\mathrm{C} 3$; and two high resistivity zones R1 and R2 (Fig. 3(C)) were identified in resistivity depth model. The feature $\mathrm{C} 1$, inferred as Kachchh Mainland Fault (KMF), is vertical up to approximately $8 \mathrm{~km}$ and north-dipping thereafter. The feature $\mathrm{C} 2$, located between sites 11 and 12, is vertical upto the depth of $20 \mathrm{~km}$ and dipping north thereafter. This feature depicts the Ulat-Kotda fault (UKF). The feature $C 3$, located between sites $14 \& 15$, is a steeply south-dipping and it coincides with the location of the Katrol Hill Fault (KHF).

Begum and Harinarayana (2016) conducted another investigation is Bhuj region. They inverted the MT profile data (Fig. 1 (A), ' 8 ') and presented a resistivity model showing the basement configuration in Bhuj earthquake epicentral zone. A sharp change in basement depths at few locations was inferred.

Geothermal source characterization near Chabsar hotwater spring site, Ahmedabad; was carried out on the basis of the resistivity model obtained from MT profiles (Figs. 1(A), 6). The inverted resistivity model, in the form depth slices, is shown in Fig. 4. A low resistivity $(<10 \Omega-\mathrm{m})$ zone is found in the depth range between 1 to $2.5 \mathrm{~km}$. A sharp contrast of resistivity divides the area into two parts along the NW-SE strike associated with deep seated $(1 \mathrm{~km})$ West Cambay Fault (WCF). The geothermal source zone is connected with the WCF which acts as a conduit for heat transfer from deeper level to shallow level.

Northern Cambay rift basin was investigated along the $200 \mathrm{~km}$ long EW profile (Fig. 1(A), '9'). The resistivity model comprises a thick conductive zone overlying sediments and resistive igneous granitic intrusion in the western part of profile. Fluid filled 


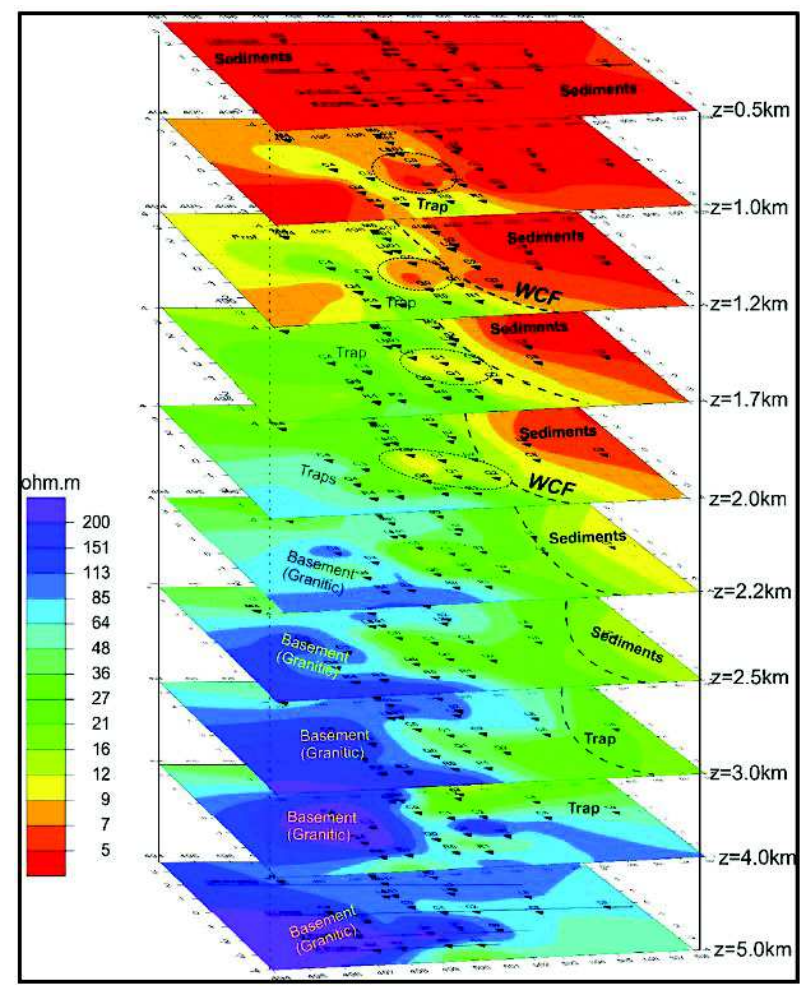

Fig. 4: The resistivity depth slices of the area (at depths given in the right hand side of each slice). Major feature (geothermal zone) is highlighted with dashed circles. The dotted black line indicates the location of West Cambay fault. WCF: West Cambay Fault. Trap: Deccan Trap (Mohan et al. 2017)

faults, shear zones and conductive sulphide mineralization zone were inferred from resistivity variations.

Transverse tectonic features in the Wagad uplift, Kachchh were delineated on the basis of MT data from 18 sites along a $60 \mathrm{Km}$ long NNE-SSW profile (Fig. 1(A), '11'). A distinct tectonic feature was identified in the block between South Wagad Fault (SWF) and North Wagad Fault (NWF). Geoelectric strike was correlated with the current seismicity pattern and trend of the pre-existing reactivated transverse fault controlling the seismicity of the active intraplate region.

Resistive and moderately conductive blocks were correlated with the lateral heterogeneities in and around beneath Jamnagar, Jasdan and western part of Cambay basin profile (Fig. 1(A), '3'). They interpreted moderately conductive block as a deepseated fault and source of Deccan volcanic eruption.
The resistive block correlates with the older crust that may have been intruded by mafic/ultramafic material due to Deccan volcanism.

\section{Dharwar Craton, Karnataka}

Three MT Studies were carried out in Dharwar Craton (DC): Billigiri rangan charnockitic massif, and Archean Dharwar craton (Fig. 1(A), '16', '17' \& ' 18 '). Regional lithosphere model of the DC shows a conductive feature in the upper mantle at a depth 120$150 \mathrm{~km}$. Western part of the Dharwar craton is explained as the kimberlite melts converted to graphite. The lithospheric thickness in the Dharwar craton is more than $200 \mathrm{~km}$ (Kusham et al. 2018).

A resistivity model was presented along a northwest-southeast oriented $220 \mathrm{~km}$ long profile (Fig. 1(A), '17'). The resistivity variations with depth show a conductor in the northern side of the profile and two distinct prominent conductors in southern part of the profile. The mid-lower crust in southern part of the profile is less resistive $(<300 \Omega-\mathrm{m})$ in the depth range between $20-50 \mathrm{~km}$, related with the Chitradurga shear zone and Billigiri Rangan charnockite massif. These zones were interpreted as $\mathrm{CO}_{2}$ flushed terranes.

Deep MT investigation were carried out at 63 locations along a $\sim 500 \mathrm{~km}$ long Chikmagalur-Kavali profile (Fig. 1(A), '16') cutting across the DC and Eastern Ghat Mobile Belt (EGMB). The inverted resistivity model shows moderately conductive features, interspersed in a highly resistive background of crystalline rocks and spatially connected to the exposed schist belts or granitic intrusions in the DC. These features were interpreted as images of fossil pathways of the volcanic emplacements associated with the greenstone belt and granite suite formation exposed in the region. Below EGMB is a thin lithosphere which forms the exterior margin of Indian shield subsequent (Malleswari et al. 2019).

\section{Eastern India}

A regional magnetotelluric (MT) survey across Dalma Volcanics (DVs) in North Singhbhum Mobile Belt (NSMB) region (Fig. 1(A), '20') was carried out to understand the metallogeny (Maurya et al. 2018). The conductivity model presents that the Singhbhum Group Metapelites (SGM) and DVs are less resistive 
whereas Singhbhum Group of Quartzite and Pelites (SGQP) are more resistive. The conducting zones carry the impression of metallogeny associated with volcanogenic massive sulfide (VMS) or volcano hosted gold deposit (Au-VMS) in the study area (Maurya et al. 2018).

Resistivity structure beneath the southward extension of the Eastern Ghats Mobile Belt (EGMB) was estimated along two profiles (Fig. 1(A), '21') the Ongole and the Nellore. The resistivity models reveal the similarities in the high resistive nature of the subsurface and these provide unequivocal evidence for the extension of EGMB from Ongole towards Nellore. On the basis of resistivity values, continuity of the EGMB beyond Ongole and towards Nellore was explained (Chandrasekhar et al. 2018).

\section{Central India}

The Central Indian Tectonic Zone (CITZ) was investigated by Azeez (2016) and Azeez et al. (2017). They interpreted MT profile data in the eastern segment of the CITZ. Under the Tan Shear zone, the north dipping conductive horizon, commencing from $7 \mathrm{~km}$ in the upper crust up to the base of the crust, is imaged. A conductive horizon characterizes the midlower crust under the Deccan trap appears to be connected to a moderately resistive (150-300 $\Omega$-m) in the mid-lower crustal zone under the Narmada Son Lineament (NSL). A low resistivity $(<10 \Omega-\mathrm{m})$ zone was observed just below the northern margin of the NSL.

\section{Maharashtra}

MT data contaminated with cultural noise from Koyna-Warna region, Maharashtra suggested that the desirable transfer functions estimates can be improved by using a combination of different processing approaches to minimize the effect of cultural noise in the data Borah et al. 2015. Patro et al. (2017) (Fig. 1(A), '25') reviewed geophysical electrical and electromagnetic (GEE) studies in Koyna-warna region and also discussed the subsurface electrical structure of the region. They rule out the presence of any subtrappean sediments in this region. The presence of well defined crustal structure characterized by high resistive blocks interspersed with moderately conductive features was delineated.

\section{Southern India}

Geoelectric structure of Palnad Sub and Nallamalai Fold Belt, Cuddapah Basins; was estimated along NW-SE profile extending between Potuluru to Anjanpalli in the NE part of Cuddapah basin along profile (Fig. 1(A), '23'). The resistivity depth model beneath the profile shows a thick low resistive (40$300 \Omega-m$ ) zone, representing sediment of Palnad Sub Basin (PSB) with thickness varying between $350 \mathrm{~m}$ to $2000 \mathrm{~m}$. The low resistivity is interpreted as the presence of base metals $(\mathrm{Cu}, \mathrm{Pb}, \mathrm{Zn})$ within the Banaganapalli quartzite and Narji limestone. A moderately low resistive feature (450-800 $\Omega-\mathrm{m})$, dipping southeast in the centre of the profile, represents Palnad sub-basin sediments entrapped along the fault zone which coincides with Nallamalai Fold Belt (NFB).

\section{D MT Studies}

Three-dimensional magnetotelluric (3D MT) is a front line area of current research both in field and in theoretical studies. In India, the three major contributions in 3D MT appeared in recent past, out of these, two are field studies by Patro and Sharma (2016) and Azeez et al. (2018) and the third is a 3D inversion software by Singh et al. (2017).

Patro and Sharma (2016) conducted MT investigations is the western segment of NarmadaSon lineament (NSL) zone in Central India (Fig. 1(A), ' 13 ') and delineated crustal resistivity structure. Location of 153 sites MT data is shown on a simplified tectonic map in Fig. 5. Inverted 3D resistivity model in the form of vertical plain slices is shown in Fig. 6. The conductive features, were interpreted as maficultramafic bodies derived from mantle. These bodies represent the intrusive component of the Large Igneous Province (LIP) of the Deccan volcanic episode triggered by the passage of the Indian continent over the reunion hot spot during the Late Cretaceous.

Another 3D MT study was conducted by Azeez et al. (2018). They recorded MT data at 37 sites, covering an approximate area of $65 \times 16 \mathrm{~km}^{2}$ in the western part of Wagad Uplift (Fig. 1(A), '12'). Locations of MT sites are shown in Fig. 7 along with the geology and tectonic features. The objective of 

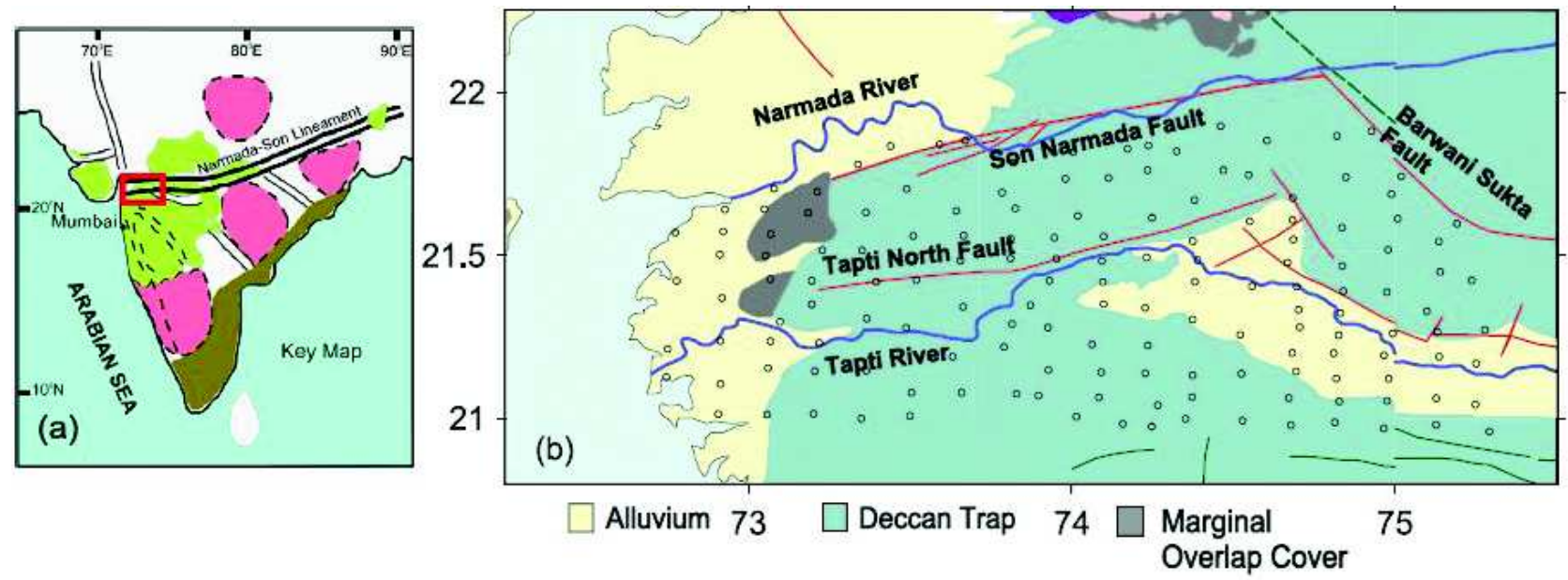

Fig. 5: (A) Tectonic map of Indian Shield showing approximate boundaries of the Precambrian craton (B). Geological map of the study region with 153 MT sites. (After Patro and Sharma 2016)

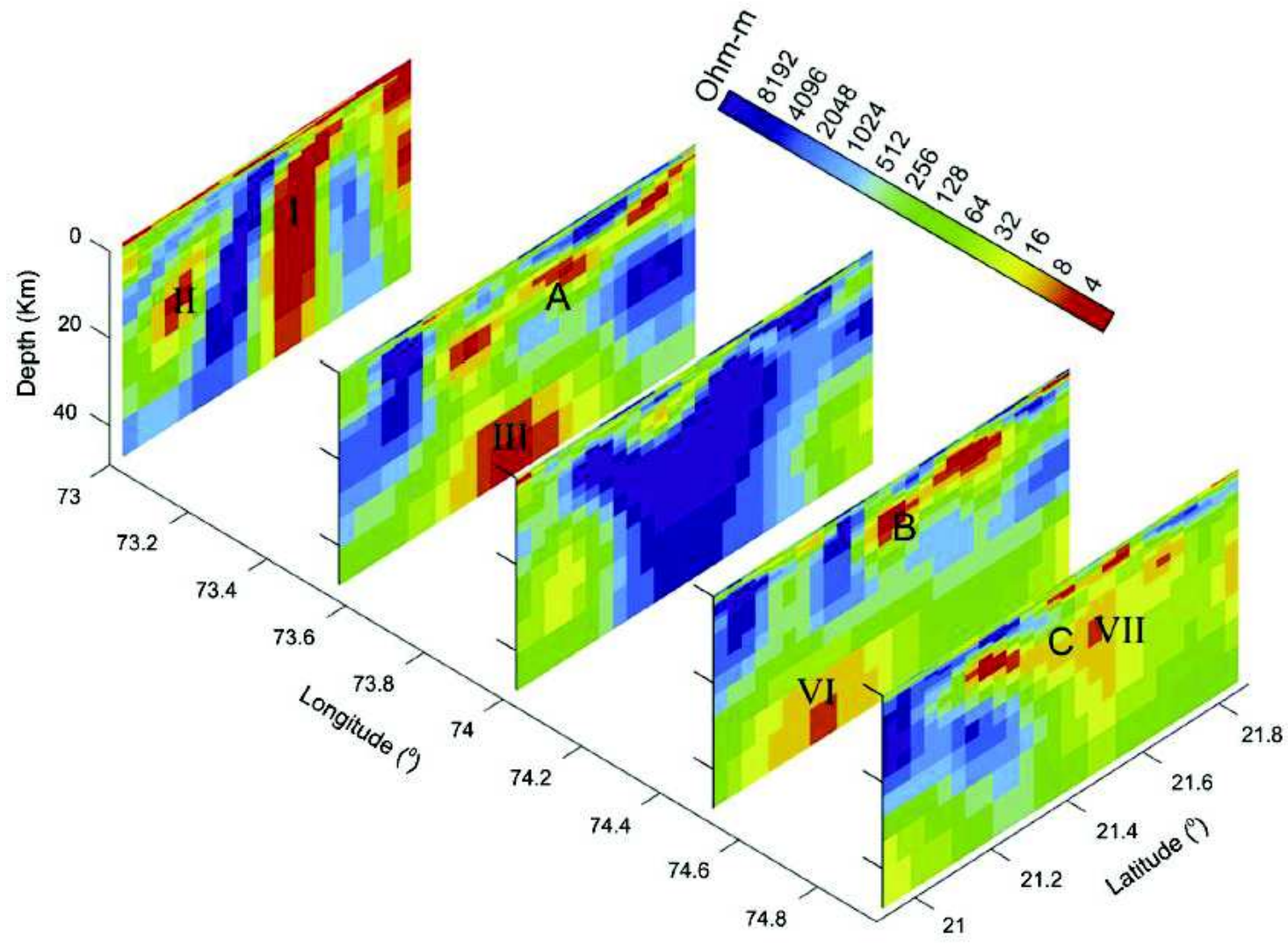

Fig. 6: N-S vertical resistivity depth sections (Patro and Sharma, 2016)

this study was to delineate the crustal geoelectric structure and to understand subsurface geometry of faults/lineaments. These provide critical information to understand the earthquake generation mechanism/ aftershocks pattern in the region. Full impedance tensor data was inverted using 3D MT inversion algorithm of Siripunvaraporn et al. (2005). The 3D resistivity model in the form four vertical plain slices are shown in Fig. 8. A thick $(\sim 3 \mathrm{~km})$ low resistivity (1$30 \Omega-\mathrm{m})$ layer depicts the Tertiary/Mesozoic sediments. Below the upper sediments, a heterogeneous upper and middle crust, characterized 


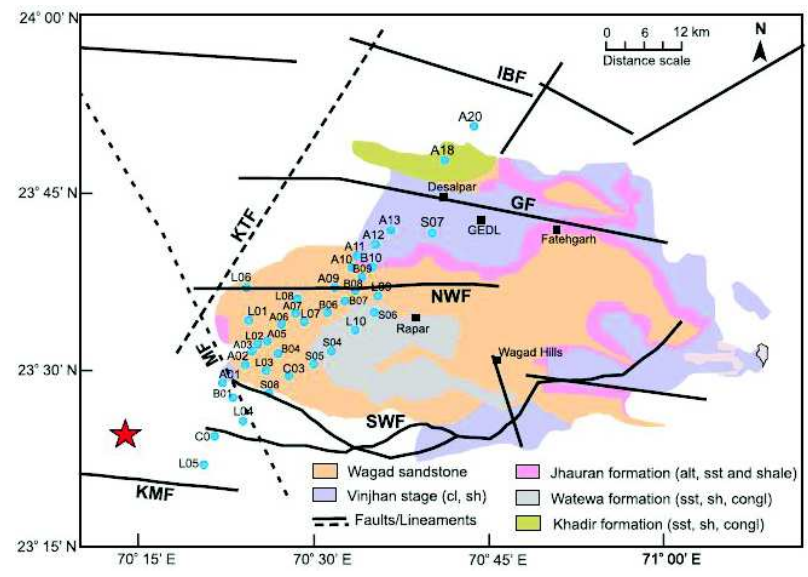

Fig. 7: Location of MT sites (solid blue circles) shown on the geology and tectonic faults/lineaments

by conductive $(<30 \Omega-\mathrm{m})$ and moderately resistive $(>300 \Omega-\mathrm{m})$ features, are delineated. Enhanced conductivity zones are interpreted as fluid enriched zones in the crust and correlates with the surface trace of various faults/lineaments. These conductive zones play an important role in earthquake triggering. The results provide a strong clue to infer that the fluid enrichment in the Khadir Transverse Fault (KTF) and Manfara Fault (MF) faults play important role in the observed seismic activity and control the aftershocks pattern.

\section{D Inversion Code}

Significant development in software aspect is a 3D MATLAB code, AP3DMT, for 3D modelling and inversion of magnetotelluric data (Singh et al. 2017). This code is made versatile and user friendly by an efficient use of MATLAB's inbuilt functions. The accuracy of the code was validated by comparing its results with the corresponding results obtained using ModEM (Egbert and Kelbert, 2012) for a variety of standard synthetic test models (Singh et al., 2017). Since this code is new to the Magnetotelluric community, we briefly explain the main features of AP3DMT code here.

The 'AP3DMT' comprises two independent components; (i) the grid generator and I/O control code and (ii) modeling and inversion code.

\section{Grid Generator}

The grid generator code includes a graphic user interface (GUI) and a standalone grid generation program. Through the GUI, one feeds the necessary input information, like units of data, frequencies, grid type and modeling and inversion control parameters. Also provided is an input model file (*.xls) containing the observation site co-ordinates and the grid and model description (synthetic and/or initial guess model). Using the information from GUI and the input model file, the grid generator code generates four files viz. parameter file, data file, model file, and covariance file. The parameter file contains the information about the forward and inversion control parameters for the iterative matrix solver, for the divergence correction, for regularization etc. The data file contains information about data like numbers of sites, frequencies, and components. In the model file the grid spacing's and the cells resistivities are provided. The covariance file provides the desired smoothening details. These files are subsequently used by the modeling/inversion code. The model grid can be designed by considering either the cuboid bodies for simple models or the polyhedron bodies for complex features. For cuboid shaped target bodies, the grids are generated on the basis of skin depth criteria. Firstly, the model domain is divided into regions on the basis of target bodies and a cell resistivity matrix is constructed. At an interface, the minimum, of the two skin depths $(\delta)$ of adjoining regions, is computed and then two grid lines are generated on either side of the interface with spacing equal to $\delta / 4$ and then $\delta / 3$ and so on. This approach ensures fine grids near the conductivity contrast to obtain accurate results in these regions. The coarseness of the grid increases as one recedes from the target model domain. Alternatively, the manual grids can be provided in the input file. This feature makes the code more user friendly as the user can assign desired grids as per the specific model requirements. To represent the complex geological structures, polyhedrons are the best choice. For example, a polyhedron oblique body is initially approximated by a cuboid which encloses the whole target body and a cell resistivity matrix is created. Uniform grids of specified size are generated for this region as a staircase model which is better suited for such bodies. In other regions of the model, the grids are generated on the basis of the skin depth criteria.

The grid generator code has been successfully tested and validated for standard complex synthetic models available in literature such as checker board 

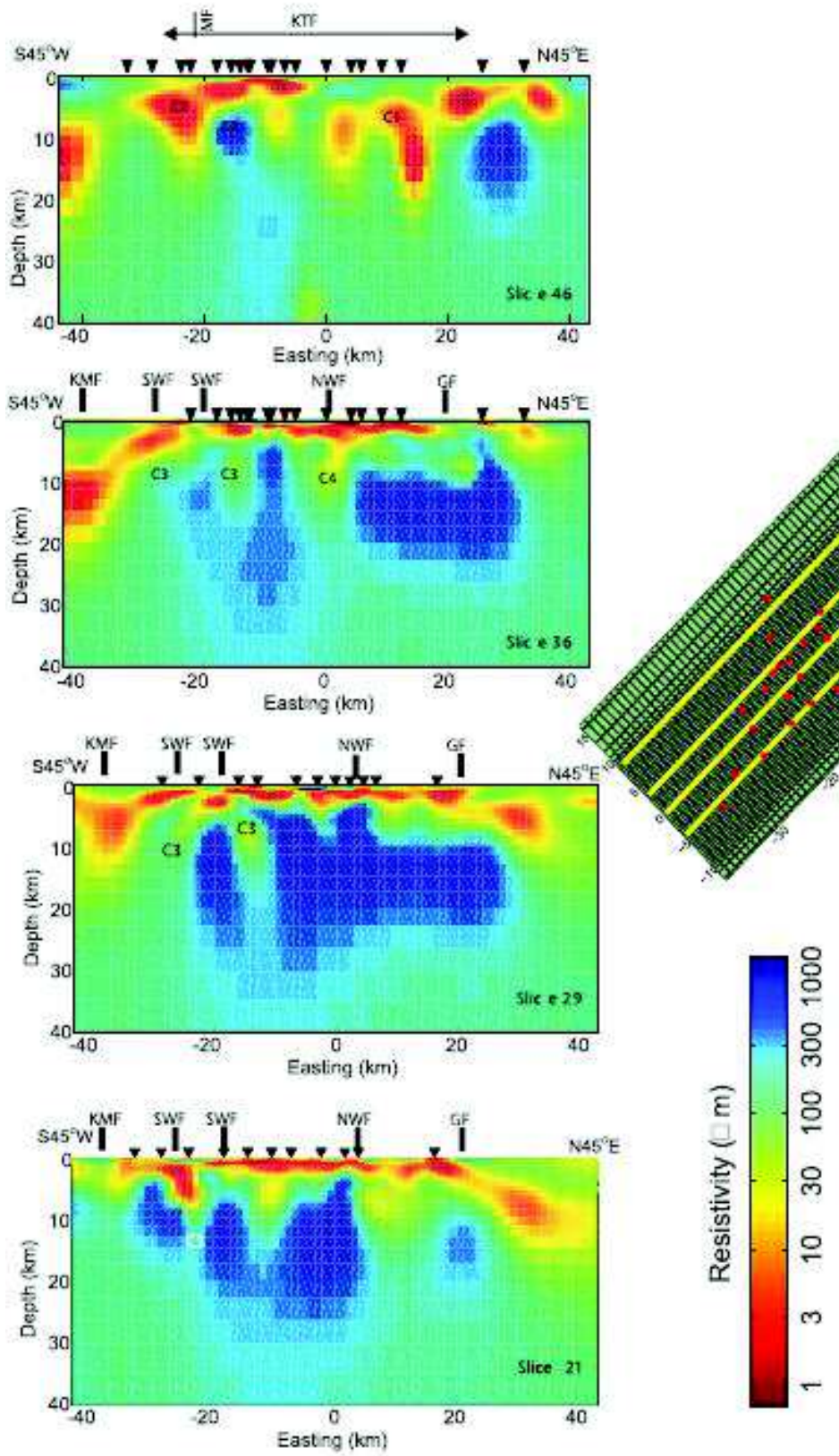

Fig. 8: 3D resistivity model extracted along four profile slices along with MT sites projected on each profile (after Azeez et al. 2018)

(Egbert and Kelbert, 2012), spiral (Meqbel, 2009) model etc.

\section{Modelling and Inversion}

The modeling and inversion code is quite flexible. For example, one can modify only the forward problem subprogram (e.g., different forward solver, different types of responses computation, model parameters, etc.) without disturbing the inversion subprogram. The $3 \mathrm{D}$ inversion implemented in ' $A P 3 D M T$ ' code is based on minimization of the following penalty functional:

$$
\begin{aligned}
\phi(m, d)= & (d-F(m))^{1} C_{d}^{-1}(d-F(m)) \\
& +\lambda\left(m-m_{0}\right)^{\mathrm{T}} C_{m}{ }^{-1}\left(m-m_{0}\right)
\end{aligned}
$$

where $\mathbf{d}$ is the observed data vector, $\mathbf{m}$ is the model cell conductivity vector, $\mathrm{F}(\mathbf{m})$ is the forward mapping function, $C_{d}$ is the data covariance matrix, $\mathbf{m}_{0}$ is the apriori model, $\mathrm{C}_{\mathbf{m}}$ is the model covariance matrix and 
Table 1: List of MT surveys groups in India during 2015-19

\begin{tabular}{|c|c|c|c|c|c|c|}
\hline S.No. & Study Area & Area/ Group & working group & $\operatorname{Pr}$ & No of sites & Major Results with reference \\
\hline 1 & Himalaya & $\mathrm{GHC}, \mathrm{SH}$ & $\begin{array}{l}\text { IITR, KUK, } \\
\text { CSRI- NGRI }\end{array}$ & 3 & 60 & $\begin{array}{l}\text { Existence of transverse tectonic feature has been discussed } \\
\text { on the basis of geoelectric strike directions estimated from } \\
\text { MT data recorded from Garhwal Himalayan corridor (Israil } \\
\text { et al. (2016) and 3D inversion (Devi et al. 2019). An updated } \\
\text { electrical resistivity model of GHC is presented (Sokolova et } \\
\text { al. 2016). Topographic correction based of the impedance } \\
\text { tensor correction algorithm is suggested with examples of } \\
\text { corrections applied on Sikkim Himalayan data (Kumar et al. } \\
\text { 2018) }\end{array}$ \\
\hline
\end{tabular}

$\begin{array}{lllll}\text { IGP } & \text { IGP } & \text { CSRI- NGRI } & 1 & 45\end{array}$
2018)

\begin{tabular}{|c|c|c|c|c|}
\hline & Gujrat & $\begin{array}{l}\text { SR, TG, KHH, } \\
\text { CH, B_EQ, } \\
\text { CB }\end{array}$ & $\begin{array}{l}\text { CSRI- NGRI, } \\
\text { IIGM. ISR, } \\
\text { KUK, AU, } \\
\text { GERMI }\end{array}$ & 14 \\
\hline
\end{tabular}

Thickness of sediments and basement topographic variation were estimated along profile between Hamirpur to Rupadiah (Manglik et al. 2015)

MT investigation in and around hot water spring,

Himmatnagar fault $(\mathrm{HnF})$, high conductive thermal influx of mantle exchange of heat to lower crust and High resistive block older Precambrian crust were explained, the sediment thickness of north dipping Kachchh Mainland Fault, and new fault were detected (Kumar et al., 2018b; Mohan et al., 2018a, 2018b). Large heat flow values in the Cambay basin filled with fluids are linked with the heat source at deeper levels (Mohan et al., 2017). Conductive features correlated with the South Wagad Fault and Kachchh Mainland Fault, basement configuration was delineated (Mohan et al. 2015, Begum and Harinarayana 2016). Basement fracturing is correlated with heat exchanger between the deeper geothermal source and nearby hot water spring (Mohan et al. 2019), 3D crustal resistivity structure beneath the Wagad aftershock zone of the 2001 Bhuj earthquake was delineated by Azeez et al. 2018). Geoelectric structure of northern Cambay rift basin were presented (Danda et al. 2017)

Processing of culturally noise contaminated data of KoynaWarna seismic zone was discussed by Borah et al. 2015. Identification of the variation of the thickness of Deccan volcanics, nature of the granitic basement and Lithospheric Electrical Structure in the Western Ghat, were presented (Patro et al. 2017 and Patro et al. 2018)

Resistivity structure was used to confirm the southward extension of the Eastern Ghat Mobile Belt beyond Ongole (Chandrasekhar et al. 2018). Low resistivity zones were correlated with the presence of gold, silver, uranium and copper deposit in the study area (Maurya et al. 2015). Near surface conductive deposit of gold and sulfide mineralization zone and sulfide mineralization in Proterozoic-Archean greenstone belts of Eastern Indian Craton were correlated with low resistivity features (Maurya et al. 2018 and Singh et al. 2018)

Extension of igneous body of large igneous province of Deccan Volcanics in the NSL region explained on the basis of resistivity model (Patro and Sharma, 2016). Conductive to moderately conductive structures were correlated to the various shear/ faults and granulitic belts and Occurrence of lower crustal Earthquake, (Azeez et al. 2017; Azeez et al. 2016) 


\begin{tabular}{|c|c|c|c|c|c|c|}
\hline & & & & & & $\begin{array}{l}\text { resistivity near Billigiri Rangan massif and resistivity structure } \\
\text { of kimberlite melts zone in Dharwar craton are discussed } \\
\text { (Malleswari et al. 2019; Pratap et al. 2018; Kusham et al. } \\
2018 \text { ) }\end{array}$ \\
\hline 8 & South India & $\mathrm{CB}$ & $\begin{array}{l}\text { IIGM, CSRI- } \\
\text { NGRI, ONGC }\end{array}$ & 1 & 16 & $\begin{array}{l}\text { Dipping resistive crustal layer in the NE parts of Cuddapah } \\
\text { basin inferred as E-W compression along the eastern margin } \\
\text { during the Neoarchaean-Neoproterozoic tectonic convergence } \\
\text { between India and east Antarctica were discussed (Konda et } \\
\text { al. 2015) }\end{array}$ \\
\hline 9 & Software & AP3DMT & IITR & & - & $\begin{array}{l}\text { MATLAB based computer code, AP3DMT, for inversion of } \\
\text { 3D Magnetotelluric data was developed and tested over } \\
\text { variety of models. }\end{array}$ \\
\hline
\end{tabular}

GHC: Garhwal Himalayan corridor, SH: Sikkim Himalaya, IGP: Indo-Gangetic Plain, SR: Saurashtra Region, TG: Tuwa-Godhra, KHH: Kachchh, CH: Chabsar, B_EQ: Bhuj Earthquake, CB: Cambay Basin, KW: Koyna Warrna, WG: Western Ghat, DV: Dalma Volcanics, EGMB: Eastern Ghat Mobile Belt, PAB: Proterozoic-Archean Greenstone Belt, NSL: Narmada Son Lineament, CITZ: Central India Tectonic zone, DC: Dharwar Craton, BRCM: Billigiri Rangan Charnockitic massif, CUB: Cuddapah basin, Pr: Profile

IITR: Indian Institute of Technology Roorkee, KUK: Kurukshetra University Kurukshetra, CSIR-NGRI: Council of Scientific and Industrial Research-National Geophysical Research Institute, IIGM: Indian Institute of Geomagnetism Mumbai, ISR: Institute of Seismological Research Gandhinagar, AU: Andhra University, GERMI: Gujarat Energy Research \& Management Institute, OU: Osmania University, ISM: IIT (Indian School of Mines) Dhanbad, IITB: Indian Institute of Technology Bombay, UCIL: Union Carbide India Limited, ONGC: Oil and Natural Gas Corporation

$\lambda$ is the trade-off parameter. In ' $A P 3 D M T$ ', the penalty functional can be minimized using either Gauss Newton with conjugate gradient method (model space or data space) or the non-linear conjugate gradient (NLCG) method (Singh et al. 2017). In the code, we implemented both the quasi-linear inversion and the non-linear inversion using conjugate gradient for the minimization of Equation 1. These algorithms require a small amount of memory usage as only the product vector of Jacobian matrix (or its transpose) with an arbitrary vector is required. The Jacobian computation is further modularized, using the decomposition approach (Egbert and Kelbert, 2012). Further, a coarse grained parallelization over number of frequencies (both forward problem and multiplication of Jacobian with a vector) is also implemented to speed up the computations. The 3D forward computations are based on the finite difference method on a staggered grid. Modular form of this code facilitates, without affecting other subprograms or modules, easy modifications needed for different forward problems (CSEM, DCR etc.).

The data set, $\mathrm{d}_{\text {obs }}$, is generally multi-frequency, multi-station and multi-component. The starting value of regularization parameter, $\lambda$, is chosen using the $\mathrm{L}$ curve (Meqbel, 2009 ). The NLCG iterations are performed for a fixed value of $\lambda$ and if the difference between the misfits of two previous iterations is less than a predefined threshold, $\lambda$ is reduced by a factor (10 for present data set). Regularization parameter $(\lambda)$ is made to decrease to a minimum value of $10^{-8}$ in present work. For regularization of the objective functional of MT inverse problem, desired model smoothness parameters can be chosen. It is achieved by constructing the model covariance matrix $\left(\mathrm{C}_{\mathrm{m}}\right)$ using the finite difference approximation to the Laplacian $\left(\nabla^{2}\right)$ operator. Isotropic or anisotropic smoothness can be chosen between 0 and 1 , as per the requirement of the data and geological inputs.

The inversion process terminates if one of the stopping criteria is fulfilled. These are: data misfit is less than the given threshold value; a local minimum occurs in case of NLCG; the data misfit starts increasing; the data value of regularization parameter $(\lambda)$ becomes smaller than the given threshold value; iteration number reaches a prescribed maximum value. This code fully functional tested and validated over standard models available in literature. More versatile and user friendly version of this code will be released soon.

\section{Conclusion}

MT studies carried out in India since 2015 is reviewed in this paper. These studied are discussed in term of 1D/2D field investigation based on the standard 
available modelling and inversion techniques. Significant step in the MT methodology in India, in recent past, is the use of 3D approach both in field and software development. MT field studies, performed in three physiographic regions: Himalayan, Indo-Gangetic plain and in Peninsular India, are summarised. 3D code for the modelling and inversion of MT was developed and tested over variety of synthetic as well as field data. MT studies have potential to provide new constraints on the crustal structure in the complex geological environment such as in Himalayan region. In future high resolution 3D MT, an emerging area of research for MT studies, may also be implemented with seismic to obtain more

\section{References}

Abdul Azeez K K (2016) Magnetotelluric Constraints on the Occurrence of Lower Crustal Earthquakes in the Intraplate Setting of Central Indian Tectonic Zone Acta Geologica Sinica English Edition 90 884-899

Azeez K A, Mohan K, Veeraswamy K, Rastogi B K, Gupta A K and Harinarayana T (2018) 3D crustal resistivity structure beneath the Wagad aftershock zone of the 2001 Bhuj earthquake, Kutch, India: Heterogeneous resistivity structure controlled by widespread fluid infiltration and clues to aftershocks pattern Tectonophysics 747 54-67

Azeez K A, Patro P K, Harinarayana T and Sarma S V S (2017) Magnetotelluric imaging across the tectonic structures in the eastern segment of the Central Indian Tectonic Zone: preserved imprints of polyphase tectonics and evidence for suture status of the Tan Shear Precambrian Research 298 325-340

Abdul Azeez K K, Veeraswamy K, Gupta A K, Babu N, Chandrapuri S and Harinarayana T (2015) The electrical resistivity structure of lithosphere across the Dharwar craton nucleus and Coorg block of South Indian shield: Evidence of collision and modified and preserved lithosphere Journal of Geophysical Research: Solid Earth 120 6698-6721

Begum S K and Harinarayana T (2016) Basement Configuration from Magnetotelluric Studies in Bhuj Earthquake Epicentral Zone, Gujarat, India Open Journal of Earthquake Research 5177

Borah U K, Patro P K and Suresh V (2015) Processing of noisy magnetotelluric time series from Koyna-Warna seismic region, India: A systematic approach Annals of Geophysics $\mathbf{5 8} 0222$ reliable image of the crustal structure and for earth resources exploration.

\section{Acknowledgements}

In this review we have included most of the magnetotelluric work carried out in India during the period from 2015-2019. We tried our best to include all the active groups and their recent contributions. However, if some research work hasn't been included in this review, it is purely due to our limitations and it is not a reflection on the importance of their contribution. We present our sincere apologies to the contributors of the work that has not been reviewed in this paper.

Borah U K and Patro P K (2017) Effect of evaluation frequency separation on magnetotelluric resolution Annals of Geophysics 600330

Chandrasekhar E, Ramesh D and Biswal T K (2018) Magnetotelluric evidence on the southward extension of the Eastern Ghats mobile belt from Ongole, India Journal of Asian Earth Sciences 164 23-32

Choudhury P, Chopra S, Roy K S and Rastogi B K (2014) A review of strong motion studies in Gujarat State of western India Natural hazards 71 1241-1257

Danda N, Rao C K and Kumar A (2017) Geoelectric structure of northern Cambay rift basin from magnetotelluric data Earth, Planets and Space 69140

Devi A, Israil M, Gupta P K, Varshney S K and Meqbel N (2019) Transverse Tectonics Structures in the Garhwal Himalaya Corridor Inferred from 3D Inversion of Magnetotelluric Profile Data Pure and Applied Geophysics 176 4921-4940

Egbert G D and Kelbert A (2012) Computational recipes for electromagnetic inverse problems Geophysical Journal International 189 251-267

Israil M, Mamoriya P, Gupta P K and Varshney S K (2016) Transverse tectonics feature delineated by modelling of magnetotelluric data from Garhwal Himalaya corridor, India Current Science (00113891) 111

Konda S, Patro P K and Rao C K (2015) Geoelectric signatures of Palnad sub basin and Nallamalai Fold Belt, Cuddapah Basin, India Journal of the Geological Society of India $\mathbf{8 6}$ 377-382

Kumar G P, Kumar V, Nagar M, Singh D, Mahendar E, Patel P and Mahesh P (2017) Magnetotelluric impedance tensor analysis for identification of transverse tectonic feature in 
the Wagad uplift, Kachchh, northwest India Journal of Earth System Science $\mathbf{1 2 6} 68$

Kumar S, Patro P K and Chaudhary B S (2018a) Three dimensional topography correction applied to magnetotelluric data from Sikkim Himalayas Physics of the Earth and Planetary Interiors 279 33-46

Kumar P V, Rao P B V, Singh A K and Rao C K (2018b) Electrical conductance map for Saurashtra region, Gujarat, India Current Science 114 2175-2181

Kumar PV, Patro P K, Rao P S, Singh AK, Kumar A and Nagarjuna D (2018c) Electrical resistivity cross-section across northern part of Saurashtra region: An insight to crystallized magma and fluids Tectonophysics $\mathbf{7 4 4} 205$ 214

Kusham, Pratap A, Naick B P and Naganjaneyulu K (2018) Lithospheric architecture in the Archaean Dharwar craton, India: A magnetotelluric model Journal of Asian Earth Sciences 163 43-53

Larsen J C (1977) Removal of local surface conductivity effects from low frequency mantle response curves Acta Geodaetica, Geophysica et Montanistica Hungarica 12 183-186

Malleswari D, Veeraswamy K, Azeez K A, Gupta A K, Babu N, Patro P K and Harinarayana T (2019) Magnetotelluric investigation of lithospheric electrical structure beneath the Dharwar Craton in south India: Evidence for mantle suture and plume-continental interaction Geoscience Frontiers 10 1915-1930

Manglik A, Adilakshmi L, Suresh M and Thiagarajan S (2015) Thick sedimentary sequence around Bahraich in the northern part of the central Ganga foreland basin Tectonophysics $65333-40$

Maurya V P, Bhattacharya B B, Adhikari P K and Das L K (2015) Preliminary magnetotelluric results across Dalma Volcanics, Eastern India: inferences on metallogeny Journal of Applied Geophysics 115 171-182

Maurya V P, Singh R K and Bhattacharya B B (2018) Magnetotelluric exploration of a deposit scale prospecting over a proterozoic volcanics, Eastern India Journal of Applied Geophysics 159 666-677

Meqbel N M M (2009) The electrical conductivity structure of the Dead Sea Basin derived from $2 D$ and $3 D$ inversion of magnetotelluric data Ph.D. thesis. Free University at, Berlin, Germany)

Mohan K, Chaudhary P, Kumar G P and Rastogi B K (2019) Magnetotelluric investigations in the southern end of the Cambay basin (near coast), Gujarat, India Journal of Applied Geophysics 162 80-92
Mohan K, Chaudhary P, Kumar G P, Kothyari G C, Choudhary V, Nagar M, Patel P, Gandhi D, Kushwaha D, Rastogi B K and Rastogi B K (2018b, 2018) Magnetotelluric Investigations in Tuwa-Godhra Region, Gujarat (India) Pure and Applied Geophysics 175 3569-3589

Mohan K, Chaudhary P, Patel P, Chaudhary B S and Chopra S (2018a, 2018) Magnetotelluric study to characterize Kachchh Mainland Fault (KMF) and Katrol Hill Fault (KHF) in the western part of Kachchh region of Gujarat, India Tectonophysics 726 43-61

Mohan K, Kumar G P, Chaudhary P, Choudhary V K, Nagar M, Khuswaha D, Patel P, Gandhi D and Rastogi B K (2017) Magnetotelluric investigations to identify geothermal source zone near Chabsar hotwater spring site, Ahmedabad, Gujarat, Northwest India Geothermics 65 198-209

Mohan K, Rastogi B K and Chaudhary P (2015) Magnetotelluric studies in the epicenter zone of 2001, Bhuj earthquake Journal of Asian Earth Sciences $\mathbf{9 8}$ 75-84

Murthy K S N, Veeraswamy K and Patro P K (2017) Modeling of Marine Magnetotelluric Response across 850E Ridge: A Numerical Simulation Journal of Indian Geophysical Union (March 2017) 21 83-95

Nam M J, Kim H J, Song Y, Lee T J and Suh J H (2008) Threedimensional topography corrections of magnetotelluric data Geophysical Journal International 174 464-474

Patro P K (2017) Magnetotelluric studies for hydrocarbon and geothermal resources: Examples from the Asian region Surveys in Geophysics 38 1005-1041

Patro P K, Raju K and Sarma S V S (2018) Some Insights into the Lithospheric Electrical Structure in the Western Ghat Region from Magnetotelluric Studies Journal of the Geological Society of India 92 529-532

Patro P K, Azeez K A, Veeraswamy K, Sarma S V S and Sen M K (2015) Sub-basalt sediment imaging - the efficacy of magnetotellurics Journal of Applied Geophysics 121 106115

Patro P K, Borah U K, Babu G A, Veeraiah B and Sarma S V S (2017) Ground electrical and electromagnetic studies in Koyna-Warna region, India Journal of the Geological Society of India 90 711-719

Patro P K and Sarma S V S (2016) Evidence for an extensive intrusive component of the Deccan Large Igneous Province in the Narmada Son Lineament region, India from three dimensional magnetotelluric studies Earth and Planetary Science Letters 451 168-176

Pratap A, Naick B P and Naganjaneyulu K (2018) A magnetotelluric study from over Dharwar cratonic nucleus 
into Billigiri Rangan charnockitic massif, India Physics of the Earth and Planetary Interiors 280 32-39

Singh A, Dehiya R, Gupta P K and Israil M (2017) A MATLAB based 3D modeling and inversion code for MT data Computers and Geosciences 104 1-11

Singh A (2018) Development of MATLAB based 3D inversion algorithm for MT and DCR data (Ph.D. Thesis, Indian Institute of Technology, Roorkee, India)
Singh S, Maurya V P, Singh R K, Srivastava S, Tripathi A and Adhikari P K (2018) Audio-magnetotelluric investigation of sulfide mineralization in Proterozoic-Archean greenstone belts of Eastern Indian Craton Journal of Earth System Science 12734

Siripunvaraporn W, Egbert G, Lenbury Y and Uyeshima M (2005)

Three-dimensional magnetotelluric inversion: data-space method Physics of the Earth and planetary interiors 150 3-14. 